\title{
A REPACTUAÇÃO DE PREÇOS À LUZ DO PRINCÍPIO DA PRESERVAÇÃO DO EQUILÍBRIO ECONÔMICO FINANCEIRO NOS CONTRATOS ADMINISTRATIVOS DE SERVIÇOS CONTÍNUOS NA ESFERA FEDERAL
}

\section{DALTON SANTOS MORAIS*}

1. Os princípios de direito como canônes para a aplicação do direito 2. Distinção entre princípios e regras - 3. A preservação do equilíbrio econômico financeiro como principio setorial de direito administrativo4. A repactuação de preços: delimitação em face do reajuste de preços, do reequilíbrio econômico financeiro e sua constitucionalidade - 5. Requisitos para a concessão de repactuação de preços pela Administração Pública-5.1. Observância de interregno mínimo de 01 (um) ano a contar da data da proposta ou orçamento - 5.2. Necessidade de prévia demonstração analítica quanto ao aumento dos custos do contrato administrativo - 5.2.1. Fixação do termo 'a quo' para a eficácia dos efeitos da repactuação de preços - 5.2.2. Necessidade de registro do acordo ou convenção coletiva de trabalho no Ministério do Trabalho - 5.2.3. Demonstração de efetiva repercussão dos fatos alegados pelo contratado nos custos dos preços inicialmente pactuados - 5.2.4. Negociação bilateral entre as partes na repactuação de preços - 5.3. Impossibilidade de repactuação de preços, mediante aplicação direta de indice de preços setoriais ou gerais de preços - 5.4. Formalização da repactuação de preços - 6. A repactuação de preços como meio para a concretização do princípio da preservação do equilíbrio econômico financeiro nos contratos administrativos de serviço contínuo na esfera federal - 7. Conclusão - 8. Referências bibliográficas.

\section{1 - Os Princípios de Direito como Canônes para a Aplicação do Direito}

O positivismo jurídico, sistema calcado no pensamento kelseniano de que um ordenamento jurídico apenas precisa de regras devidamente escalonados em ordem

* Procurador federal, membro da Advocacia-Geral da União. dalton@ibge.gov.br.

R. Dir. Adm.,

Rio de Janeiro, 233: 245-260,

Jul./Set. 2003 
hierárquica, sem qualquer consideração de ordem metajurídica, possibilitou, na Alemanha nazi-facista, a existência de um Estado de Direito no qual se praticou, sob a égide da lei, o extermínio de milhares de vidas.

Chocado, o pensamento jurídico hodierno passou a rejeitar a idéia de um ordenamento que tivesse, como uma única fonte de validade, uma norma jurídica de maior hierarquia, pressupostamente, elaborada pelo Estado.

Neste cenário surge o pós-positivismo, movimento capitaneado por juristas e

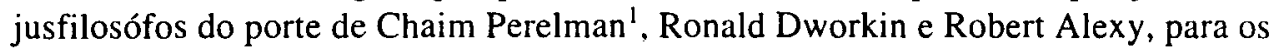
quais os valores não poderiam ficar de fora da aplicação do Direito, devendo esta levar em consideração os princípios orientadores da conexão entre o Direito e a Moral.

Como precursores da difusão do pós-positivismo no Brasil podemos fazer uma insuperável referência a Paulo Bonavides, sendo digna de menção neste aspecto, em relação ao cenário fluminense, a colaboração de nomes como Antônio Cavalcanti Maia e Ricardo Lobo Torres, professores de dois centros de excelência na difusão nacional deste atual modo de pensar o direito, quais sejam os cursos de pós-graduação strictu sensu em Direito da PUC-RJ e da UERJ.

Com base na difusão deste hodierno pensamento jurídico no cenário nacional, consolidou-se a importância dos princípios de direito como espécie de norma, com total hegemonia e preeminência, devido à carga valorativa que os informam.

Não sendo possível falar adequadamente sobre tema tão complexo em tão poucas linhas, basta-nos, neste momento, expor que, sendo os princípios de caráter eminentemente normativo, funcionam os mesmos como canônes na aplicação do direito, devido à forte incidência sobre os mesmos dos valores adotados pela sociedade em dado momento histórico.

\section{2 - Distinção entre Princípios e Regras}

Conforme expõe o atual pensamento jurídico, os princípios e as regras são espécies diversas do gênero norma jurídica, sendo ambos de caráter geral e abstrato e dotados de imperatividade.

Mas, em que pese a unanimidade em dotar os princípios de caráter normativo, ainda não há, na moderna doutrina, consenso quanto aos critérios para a configuração dos princípios de direito e, especialmente, quanto à sua distinção em relação às regras jurídicas.

1 O filósofo belga insurgiu-se contra as consequiências da abordagem positivista - levada a efeito pelo empirismo lógico do Círculo de Viena - quanto à argumentação racional sobre valores, já que aquela relegava "ao decisionismo todas as opções referidas a valores fundamentais no campo da política e sobretudo do Direito". In Os Princípios de Direito e as Perspectivas de Perelman, Dworkin e Alexy. Os Princípios da Constituição. Rio de Janeiro: Lumen Juris, 2001. 
Segundo Jane Reis Gonçalves Pereira e Fernanda Duarte Lopes Lucas da Silva ${ }^{2}$, Ronald Dworkin prega a distinção dos princípios e regras a partir de um aspecto lógico:

"Ambos (regras e princípios) estabelecem standards que apontam para decisões particulares relativas a obrigações jurídicas em determinadas circunstâncias, mas diferem quanto ao caráter da orientação que estabelecem. As regras são aplicáveis à maneira do tudo ou nada. Se os fatos que a regra estipula estão dados, então ou a regra é válida, caso em que a resposta que fornece deve ser aceita, ou então não é, caso em que nada contribuirá para a decisão." 3

Robert Alexy, embora o faça em contexto teórico diverso de Ronald Dworkin, também diferencia regras e princípios, sob o aspecto lógico ou qualitativo. Para o autor alemão, a distinção entre princípios e regras é melhor evidenciada a partir dos casos de colisão entre as normas, já que os conflitos entre regras são solucionados com base nos aspectos de validade da norma, considerando-se os critérios hierárquico, cronológico ou da especialidade, enquanto os conflitos entre princípios são solucionados a partir da ponderação quanto ao peso de cada princípio, consideradas as circunstâncias do caso concreto.

Significa dizer que, no conflito entre princípios, não há extinção do princípio de menor adequação valorativa à hipótese do caso concreto, mas tão-somente o seu simples afastamento, continuando o mesmo inserto no ordenamento jurídico vigente, podendo ser aplicado em outro caso concreto em que sua carga valorativa seja mais adequada.

Com base em tais posicionamentos, podemos evidenciar dois critérios para a distinção entre princípios e regras, quais sejam a forma de aplicação e o conflito de normas e sua solução.

Quanto à forma de aplicação, considerando-se o ensinamento de Robert Alexy de que os princípios podem ser caracterizados como mandados de otimização, verifica-se que os mesmos podem ser implementados segundo várias escalas de concretização, de acordo com as circunstâncias fáticas e jurídicas que envolvam o caso concreto. Já as regras impõem uma exigência que é ou não cumprida, não permitindo a sua concretização em diversos graus, tal como ocorre nos princípios.

E, quanto ao conflito de normas e sua solução, verifica-se que a distinção feita entre princípios e regras, diz respeito à convivência entre princípios de maior ou menor peso, de acordo com o caso concreto, enquanto as regras antinômicas excluem-se do ordenamento jurídico, face à perda de validade da regra não aplicável ao caso concreto.

2 A Estrutura Normativa das Normas Jurídicas in Os Princípios da Constituição de 1988. Rio de Janeiro: Lumen Juris, 2001, pp. 3 a 24.

3 Idem ibdem, p. 9. 
Diante de tais considerações quanto à distinção entre princípios e regras, de acordo com o mais moderno pensamento jurídico, poderemos configurar a preservação do equilíbrio econômico financeiro dos contratos administrativos como princípio de direito.

\section{3 - A Preservação do Equilíbrio Econômico Financeiro como Princípio Setorial de Direito Administrativo}

$O$ equilibrio econômico financeiro nos contratos administrativos tem matiz constitucional, tal como se depreende do art. 37, XIII da Constituição da República, o qual tem como uma de suas disposições que sejam "mantidas as condições efetivas da proposta" vencedora do certame licitatório. ${ }^{4}$

Diante da constitucionalização da norma, diversos são os administrativistas que elencam a preservação do equilíbrio econômico financeiro no contrato administrativo como princípio de direito.

Opina CAIO TÁCITO:

"O equilíbrio econômico financeiro do contrato é, na expressão de Waline, "um direito fundamental" de quantos pactuam com o Estado, ou uma "norma fundamental da teoria dos contratos administrativos", segundo De Soto. Constitui o "primeiro direito original do co-contratante da Administração", esclarece Péquignot e deve ser respeitado como "elemento determinante do contrato", conforme Laubadère.

O princípio visa, sobretudo, à correlação entre encargos e a remuneração correspondente, de acordo com o espírito lucrativo que é elementar aos contratos administrativos e, especialmente, à concessão do serviço público." 5

Mas em que pese tão renomada opinião, mister aprofundar-se, de acordo com o hodierno pensamento pós-positivista, quanto à caracterização da preservação do equilibrio econômico financeiro no contrato administrativo como princípio.

A existência de conflito de normas relativo a caso concreto, quanto à necessidade de preservação do equilíbrio contratual, não poderá ser resolvido sob o aspecto do "tudo ou nada" relativo ao conflito de regras, isto porque sendo o equilíbrio econômico financeiro postulado constitucionalmente fixado, não pode o mesmo ser retirado do ordenamento jurídico, considerando-se tão-somente critérios de validade da norma. Ao que nos parece, poderia a preservação do equilíbrio contratual ser momen-

4 "O direito à manutenção do equilíbrio econômico financeiro da contratação não deriva de cláusula contratual nem de precisão no ato convocatório. Tem raiz constitucional." Marçal Justem Filho. Comentários à Lei de Licitações e Contratos Administrativos. São Paulo: Dialética, 2000. p. 558.

5 Temas de Direito Público: Estudos e Pareceres. Rio de Janeiro: Renovac, 1997. p. 201. 
taneamente afastado, caso seja de maior valor outro princípio, considerando-se as circunstâncias do caso concreto, sem ser, com isso, retirado definitivamente do ordenamento jurídico.

Também quanto à forma de aplicação, a preservação do equilíbrio econômico financeiro no contrato administrativo parece-nos se delinear como princípio. Isto porque, de acordo com as circunstâncias fáticas do caso concreto, a preservação da adequada relação econômica financeira pode apresentar-se sob vários graus de concretização, podendo variar do total restabelecimento da dita relação até a manutenção do desequilíbrio, por simples acordo de vontade entre as partes contratantes.

Ademais, cabe-nos frisar o ensinamento de Manoel Messias Peixinho de que, quer esteja explícito na Constituição da República ou na legislação infraconstitucional, quer seja um princípio implícito, somente poderá ser caracterizado como canône normativo (princípio) para a Administração Pública o postulado que objetive uma realização ótima da atividade administrativa ${ }^{6}$, ressaltando ainda o professor que o princípio, no âmbito administrativo, será setorial, caso se relacione com um dos capítulos do Direito Administrativo.

Sendo a nossa ordem econômica, segundo dispõe o art. 170 caput, incisos II e IV da Constituição da República, fundada na livre iniciativa, na propriedade privada e na livre concorrência, é fácil verificar-se a importância de manutenir-se a relação econômica financeira para a sobrevivência econômica de qualquer contratante, principalmente para aquele que ajusta com o Poder Público, o qual detém as chamadas cláusulas exorbitantes.

Diante das referidas cláusulas exorbitantes a que tem direito a Administração Pública - detentora do inegociável interesse público - na execução do contrato administrativo, sobressai-se a importância da necessidade de preservação da adequada relação econômica financeira, inicialmente pactuada, como suporte imprescindível para atingir-se o objeto pretendido pela Administração Pública.

Portanto, sendo a manutenção do ajuste econômico financeiro imprescindível para que o contratado execute - em uma economia de mercado capitalista como a brasileira - 0 objeto contratual desejado pela Administração Pública, pode-se caracterizar o postulado da preservação do equilíbrio econômico financeiro, o qual visa à otimização da atividade administrativa, como princípio setorial de direito administrativo.

4- A Repactuação de Preços: Delimitação em Face do Reajuste de Preços, do Reequilíbrio Econômico Financeiro e sua Constitucionalidade

A Lei de Licitações e Contratos Administrativos prevê que o valor pactuado inicialmente entre as partes pode sofrer alterações de três espécies: reajuste (art. 40,

6 Princípios Constitucionais da Administração Pública in Os Princípios da Constituição de 1988. Rio de Janeiro: Lumen Juris, 2001. p. 452/453. 
XI), atualização financeira em decorrência de atraso no pagamento (art. 40, XIV, alínea $c$ ) e reequilíbrio econômico financeiro (art. 65, II, alínea $d$ ).

$O$ reajuste de preços, tal como previsto no art. 40, XI da Lei $n^{\circ} 8.666 / 93$, indica a reposição da perda do poder aquisitivo da moeda, através da aplicação de índices de preços pré-fixados no contrato administrativo.

Já o reequilíbrio econômico financeiro strictu sensu trata-se de restabelecimento do sinalagma contratual inicialmente pactuado pelas partes, desde que o mesmo tenha sido alterado por álea extraordinária superveniente ao originalmente contratado. A aplicação do reequilíbrio econômico financeiro ao contrato administrativo decorre, nas palavras de CAIO TÁCITO, da adoção do equilíbrio econômico financeiro como "princípio geral de direito que harmoniza a alteração das obrigações em benefício do interesse público com o reconhecimento do direito de justa remuneração do empresário particular, que colabora com a Administração Pública". Instituto legalmente previsto no art. 65 da Lei 8.666/93, só pode ser concedido ao contratado pela Administração, desde que se verifique a ocorrência das hipóteses específicas de sua admissibilidade delineadas pela Lei.

Especificamente para os contratos administrativos de serviços contínuos na esfera federal, o Decreto $n^{\circ} 2.271 / 97$ e a IN MARE $n^{\circ} 18 / 97$ prevêem a repactuação de preços como mecanismo para manutenir a relação econômica financeira do contrato.

A repactuação de preços - conforme definição legal exposta ao art. $5^{\circ}$ do Decreto 2.271 de 07.07.97 e ao item 7 da Instrução Normativa MARE $n^{\circ} 18 / 97^{7}-$ visa adequar os preços dos contratos administrativos - exclusivamente os que tenham como objeto a prestação de serviços contínuos - aos novos preços de mercado, através da implementação dos efetivos aumentos de custos aos preços da atividade contratada, demonstrados através de planilhas de custos e formação de preços. Aplica-se somente aos casos previstos no Decreto e na Instrução Normativa acima mencionados, segundo as condições e requisitos ali previstos para sua implementação, tendo como forte objetivo o restabecimento do ajuste inicialmente pactuado, através da consideração dos aumentos efetivamente ocorridos nos custos contratuais, evitando assim o repasse automático de índices de preços, o que colabora com a interrupção da cadeia nociva de indexação econômica aos contratos.

7 Decreto $n^{\circ} 2.271 / 97:$ “ Art. $5^{\circ}$ Os contratos de que trata este Decreto, que tenham por objeto a prestação de serviços executados de forma contínua poderão, desde que previsto no edital, admitir repactuação visando a adequação aos novos preços de mercado, observados o interregno mínimo de um ano e a demonstração analítica da variação dos componentes dos custos do contrato, devidamente justificada.

Instrução Normativa MARE n 18/97: “7. Da Repactuação de Preços. 7.1 Será admitida a repactuação do contrato, desde que seja observado o interregno mínimo de um ano a contar da data da proposta, ou da data do orçamento a que a proposta se referir, ou da data da última repactuação. 7.2 Será dotada como data do orçamento a que a proposta se referir, a data do acordo, convenção, dissídio coletivo de trabalho ou equivalente, que estipular o salário vigente à época da apresentação da proposta, vedada a inclusão, por ocasião da repactuação, de antecipações e de benefícios não previstos originariamente. $7.3 \mathrm{~A}$ repactuação será precedida de demonstração analítica do aumento de custos, de acordo com a Planilha de Custos e Formação de Preços referida no subitem 1.1.5." 
Vedada a inovação normativa por meio de decreto, nos termos do art. 84, IV da CF, há autores que entendem ser a repactuação de preços inconstitucional, sob o argumento de que o instituto não poderia ter sido criado por norma inscrita em decreto - art. $5^{\circ}$ do Decreto ${ }^{\circ} 2.271 / 97$.

Em nosso entender tal posicionamento não resiste a considerações mais consistentes sobre o tema. Isto porque, por força da supremacia constitucional e da presunção de constitucionalidade das leis, é norma de hermenêutica constitucional que os atos normativos devam ser interpretados conforme a Constituição da República. ${ }^{8}$ $\mathrm{E}$, ao que nos parece, a repactuação de preços não foi editada pelo Decreto ${ }^{\circ}$ 2.271/97 como uma figura autônoma, mas sim como uma espécie de reajuste de preços, a qual, ao invés de utilizar-se da aplicação de índices de preços, considera tão-somente a efetiva alteração dos custos contratuais.

Tal posicionamento tem embasamento no delineamento dos institutos pelas disposições legais que os fundamentam. A repactuação de preços tem como requisitos para sua concessão a necessidade de previsão contratual e interregno temporal mínimo - art. $5^{\circ}$ caput do Decreto $n^{\circ} 2.271 / 97$ e item 7 da IN IN MARE $n^{\circ} 18 / 97$ - requisitos os quais também estão presentes no reajuste de preços - art. 55, III da Lei $n^{\circ} 8.666 / 93$ e art. $3^{\circ}, \S 1^{\circ}$ da Lei $n^{\circ} 10.192 / 01$.

Ora, a repactuação de preços, apesar da sua característica de negociação bilateral, tem por finalidade adequar a relação econômica financeira do contrato administrativo de serviços contínuos, tal como o reajuste de preços, diferenciando-se os institutos pelo meio utilizado para tanto e pela amplitude com que os mesmos são aplicáveis no âmbito federal. Enquanto o reajuste de preços aplica diretamente índices de preços, recaindo genericamente sobre os contratos administrativos, a repactuação de preços aplica-se exclusivamente aos contratos administrativos de serviços contínuos, podendo considerar tão-somente a efetiva alteração dos custos contratuais, através de sua demonstração pela comparação entre planilhas de preços e custos inerentes à contratação.

Diante do exposto, percebe-se que, na verdade, a repactuação de preços não se trata de figura jurídica autônoma, mas sim espécie de reajuste de preços, regulamentada pelo Decreto ${ }^{\circ} 2.271 / 97$ e pela In MARE $n^{\circ} 18 / 97$, estando, portanto, isenta de inconstitucionalidade quanto ao aspecto previsto no art. 84, IV, última parte da Constituição da República.

8 "A supremacia das normas constitucionais no ordenamento jurídico e a presunção de constitucionalidade das leis e atos normativos editados pelo poder público competente exigem que, na função hermenêutica de interpretação do ordenamento jurídico, seja sempre concedida preferência ao sentido da norma que seja adequado à Constituição Federal. Assim sendo, no caso de normas com várias significações possíveis, deverá ser encontrada a significação que apresente conformidade com as normas constitucionais, evitando sua declaração de inconstitucionalidade e consequiente retirada do ordenamento jurídico." Alexandre de Moraes. Direito Constitucional. $3^{\mathbf{a}}$ Ed. São Paulo: Atlas, 1998. p. 41. 
5 - Requisitos para a Concessão de Repactuação de Preços pela Administração Pública

A repactuação de preços, como forma de preservar a adequada relação econômica financeira do contrato administrativo, através da negociação bilateral entre as parte, tal como previsto nó art. $5^{\circ}$ do Decreto $n^{\circ} 2.271$, de 07 de julho de 1997, e no item 7 da Instrução Normativa MARE $n^{\circ} 18$, de 22 de dezembro de 1997, é condicionada à existência de certos requisitos, conforme adiante se verá.

\section{1 - Observância de Interregno Mínimo de 01 (um) Ano a Contar da Data da Proposta ou do Orçamento}

O primeiro requisito diz respeito a não ter decorrido prazo inferior a 12 (doze) meses, a contar da data da proposta, ou da data do orçamento a que a proposta se referir ou da última repactuação concedida, nos termos do que determina o item 7.1 da IN MARE $n^{\circ} 18 / 97$.

Quanto ao requisito acima exposto, cabe-nos ressaltar que o Tribunal de Contas da União entende ser o referido ato normativo apto a regular a repactuação de preços nos contratos administrativos.

Dispõe o art. 7.1 da $I N$ MARE $n^{\circ}$ 18/97:

"7.1 Será permitida a repactuação do contrato, desde que seja observado o interregno mínimo de um ano, a contar da (...) data da última repactuação;"

Sobre o referido dispositivo, o DLSG/SLTI do Ministério do Planejamento, Orçamento e Gestão assim se manifestou:

“Neste caso, será adotado o contido no subitem 7.1 e 7.2 da IN/MARE n $18 / 97$, que trata da repactuação, considerando que deverá ter transcorrido, no mínimo, um ano, a contar da data da proposta, ou da data do orçamento a que a proposta se referir, ou da data da última repactuação, estando estas disposições de acordo com a Lei $n^{\circ} 9.069 / 95$ e a Lei $n^{\circ} 10.192 / 2001 . " 9$

\section{2 - Necessidade de Prévia Demonstração Analítica quanto ao Aumento dos} Custos do Contrato Administrativo

Estabelecem o art. $5^{\circ}$ caput do Decreto $n^{\circ} 2.271 / 97$ e o item 7.3 da IN MARE $n^{\circ} 18 / 97$ que a repactuação de preços será precedida de demonstração analítica do aumento de custos do contrato.

O supramencionado requisito tem por finalidade aferir subrequisitos para a repactuação de preços, quais sejam: 
5.2.1. Fixação do Termo a quo para a Eficácia dos Efeitos da Repactuação de Preços

Tal matéria não é pacífica no seio da doutrina nacional, pois há posicionamentos divergentes quanto à data a partir da qual seria devida a repactuação de preços ao contratado.

Há uma corrente doutrinária no sentido de que a repactuação de preços tem que ser concedida ex officcio pela Administração. Neste sentido:

“Assim, chegado o momento da repactuação, a Administração, de ofício, averigua, analiticamente, a variação dos componentes dos custos do contrato e, se for o caso, procede à repactuação." 10

Entretanto, em que pese o posicionamento acima exposto, a jurisprudência do Tribunal de Contas da União dá-se no sentido de que a data do requerimento de repactuação, acompanhiado da respectiva Planilha de Custos, pela contratada pode definir o momento a partir do qual seria devida, se aprovada pela Administração Pública, a repactuação do preço contratado.

Acompanhando tal posicionamento da Corte de Contas, a Auditoria Interna do Ministério Público da União firmou orientação - em consulta formulada pela Procuradoria da República em Santa Catarina; Processo Audin n 2002/02650 e 2804 - neste sentido:

“Deverá, entretanto, ser solicitada pela empresa, constituindo assim o momento inicial das negociações. Reafirmamos, entretanto, que o prazo para pagamento de novos valores repactuados deverá iniciar-se sempre a partir da conclusão das negociações, ou no máximo, poderá retroagir à data da solicitação da contratada."

Entretanto, a IN MARE ${ }^{\circ} 18 / 97$, como ato normativo integrante de legislação regulamentar, não pode ser interpretada de forma a atingir objetivos distintos dos princípios que regem a atuação administrativa, em especial, o princípio da vedação do enriquecimento sem justa causa pela Administração em detrimento do particular contratado.

E sendo a vedação ao enriquecimento sem justa causa um princípio de direito deve o mesmo ser observado pela Administração Pública, em especial, na execução de seus contratos.

Neste sentido, posiciona-se Celso Antônio Bandeira de Mello:

“5. Enriquecimento sem justa causa é o incremento do patrimônio de alguém em detrimento do patrimônio de outrem, sem que, para supeditar tal evento,

10 Consulta em Destaque, Informativo de Licitaçōes e Contratos. Ed. Zênite. Maio/2001, n ${ }^{\circ} 87$, fls. $388 / 393$. 
exista uma causa juridicamente idônea. É perfeitamente assente que sua proscrição constitui-se em um princípio geral de direito.

(...)

Igualmente felizes são as averbações de O. A. BANDEIRA DE MELLO ao anotar que tais princípios "se infiltram no ordenamento jurídico de dado momento histórico" ou que traduzem "o mínimo de moralidade que circunda o preceito legal, latente na fórmula escrita ou costumeira" e ao ressaltar que são "as teses jurídicas genéricas que informam o ordenamento jurídico-positivo do Estado", conquanto não se achem expressadas em texto legal específico. No exemplário de tais princípios gerais, o autor menciona, entre outros, o de que ninguém deve ser punido sem ser ouvido, o do enriquecimento sem justa causa, o de que ninguém pode se beneficiar da própria malícia etc. (Princípios Gerais de Direito Administrativo, vol. I, pp. 406407, Ed. Forense, $2^{a}$ ed., 1979).

6. Uma vez que o enriquecimento sem justa causa é um princípio geral de direito - e não apenas princípio alocado em um de seus braços: público ou privado - evidentemente também se aplica ao direito administrativo.

\section{(...)}

11. De todo modo, como se vê, por um ou outro fundamento, o certo é que não se pode admitir que a Administração se locuplete à custa alheia e, segundo nos parece, o enriquecimento sem causa - que é princípio geral do Direito - supedaneia, em casos tais, o direito do particular indenizar-se pela atividade que proveitosamente dispensou em prol da Administração (...)." (grifos do autor) ${ }^{11}$

Ainda no sentido de que não é permitido enriquecimento sem justa causa pela Administração Pública em seus contratos, preleciona CAIO TÁCITO:

“(...) a manutenção rígida das cláusulas financeiras do contrato administrativo, quando seu pressuposto não mais subsiste, assume aspecto de enriquecimento injusto, senão mesmo ilícito, por parte da Administração." 12

Portanto, com base no princípio da vedação ao enriquecimento sem justa causa, bem como na interpretação do item 7.2 da IN MARE $n^{\circ}$ 18/97 de acordo com o referido princípio, pode-se firmar como marco inicial da repactuação de preços a data de vigência do salário normativo sobre o qual foi feito o requerimento pela contratada.

11 O Princípio do Enriquecimento sem Justa Causa em Direito Administrativo. Revista Diálogo Jurídico, Salvador, CAJ - Centro de Atualizaçāo Jurídica, v.I, n², maio/2001.

12 Temas de Direito Público: Estudos e Pareceres. Rio de Janeiro, Renovar, 1997, p. 630. 
Ainda nesta linha de raciocínio, o DLSG/SLTI do Ministério do Planejamento, Orçamento e Gestão assim se manifestou:

"O prazo para concessão de repactuação será a data do pedido da empresa, podendo retroagir até a data do acordo, convenção ou dissídio coletivo, inclusive considerando a vigência deste instrumento legal quando retroativo." 13

É assim, tendo os posicionamentos supramencionados embasamento jurídico, poderá a Administração Pública contratante fixar como início da eficácia dos efeitos da repactuação a data de requerimento da contratada ou retroagir aquele termo $a$ quo à data inicial de vigência dos salários-normativos em relação aos quais se realiza a repactuação.

\subsubsection{Necessidade de Registro do Acordo ou Convenção Coletiva de Trabalho no Ministério do Trabalho}

Cabe-nos ressaltar que, quando o requerimento de repactuação recair sobre a majoração do salário normativo da categoria inerente aos serviços contratados, o acordo ou convenção coletiva de trabalho que majorou o referido salário normativo deverá ter seus instrumentos juntados aos autos de processo administrativo, sendo requisito imprencindível que o ajuste coletivo de trabalho esteja registrado e arquivado na Delegacia Regional do Trabalho, em atendimento às disposições dos ats. $614 \S 1^{\text {o14 }}$ da CLT.

Sem o arquivamento e registro da Convenção Coletiva no Ministério do Trabalho, a mesma não entra em vigor e, portanto, não poderá ser concedida a repactuação pleiteada.

\subsubsection{Demonstração de Efetiva Repercussão dos Fatos Alegados pelo} Contratado nos Custos dos Preços Inicialmente Pactuados

Este é o entendimento da jurisprudência do Tribunal de Contas da União sobre o disposto na IN MARE $n^{\circ} 18 / 97$, conforme abaixo se verifica:

"8.7 na repactuação de seus contratos de serviços de natureza contínua efetuada nos termos da IN 18/97/MARE, confira se ocorreu de fato o

$13 \mathrm{Fax} \mathrm{n}^{\circ} 739 / 2002$ de 07.08.2002, DLSG/SLTI/MPOG

14 Art. 614 Os sindicatos convenientes ou as empresas acordantes promoverão, conjunta ou separadamente, dentro de 8 (oito) dias da assinatura da Convenção ou Acordo, o depósito de uma via do mesmo, para fins de registro e arquivo, no Departamento Nacional do Trabalho (atualmente Secretaria de Emprego e Salário), em se tratando de instrumento de caráter nacional ou interestadual, ou nos órgãos regionais do Ministério do Trabalho, nos demais casos.

$\S 1^{\circ}$ - As convenções e os acordos entrarão em vigor 3 (três) dias após a data de entrega dos mesmos no órgão referido neste artigo." 
aumento de custos alegado pela contratada, por meio de minucioso exame da Planilha de Custos e Formação de Preços apresentada, sendo que, caso seja deferido o pedido, tal estudo subsidie as justificativas formuladas pela autoridade competente." (grifo nosso) ${ }^{15}$

Necessário, portanto, que a Administração Pública contratante compare as Planilhas de Custos e Formação de Preços fornecidas pela contratada por ocasião da apresentação da proposta e do requerimento de repactuação, verificando se ocorreu ou não a efetiva repercussão dos eventos majoradores nos custos do pactuado originalmente.

\subsubsection{Negociação Bilateral entre as Partes na Repactuação dos Preços}

Conforme já exposto neste trabalho, entende-se a repactuação não como mero repasse de índices aos preços pactuados, mas sim como negociação bilateral, a qual deve ser aprovada antes de ser concedida ao contratado que a requereu.

Em consonância com este entendimento:

"Nesse contexto, lembramos, reiteradamente, que repactuação implica negociação e não repasse integral de índices de reajuste, sendo dever do gestor público envidar esforços a fim de reduzir os custos operacionais, observadas as normas legais e o contrato." 16

Deve, portanto, a Administração Pública contratante, através da negociação bilateral, envidar esforços no sentido de, sem prejudicar a adequada relação econômica financeira do contrato, reduzir custos para a atividade administrativa, certificando-se, ainda, de que os preços - caso aprovada a repactuação - encontrar-se-ão de acordo com os valores de mercado, verificando se a contratação continua vantajosa à Administração Pública contratante.

De acordo com tal orientação posicionou-se a Auditoria Interna do Ministério Público da União:

"Salientamos que cabe ao gestor do contrato, de posse da demonstração analítica da variação dos componentes dos custos, devidamente justificada, e, principalmente, da planilha inicial, que se subsumem à aplicação do Decreto $n^{\circ} 2.271 / 97$ e da IN supra, haja vista também as condições de mercado, avaliar o pleito referente à repactuação e formar seu juízo de conviç̧ão." 17

15 Voto do Ministro Relator no Processo n 003.993/1999-0 - Tribunal de Contas da União.

16 Dica do Mês, Informativo Audin $n^{\circ} 131$, junho/2000.

17 Dica do Mês, Informativo Audin $n^{\circ} 131$, junho/2000. 
5.3 - Impossibilidade de Repactuação de Preços, mediante Aplicação Direta de Índice de Preços Setoriais ou Gerais de Preços

Qualquer contrato, seja administrativo ou não, deve obediência à legislação vigente e pertinente à matéria que pretende regular. Nos contratos administrativos de prestação de serviços contínuos, conforme já mencionado anteriormente, $o$ ajuste deve obediência ao Decreto $n^{\circ}$ 2.271/97 e à IN MARE $n^{\circ}$ 18/97, legislação esta que deverá estar expressamente consignada no preâmbulo contratual.

Dispōe o Decreto $n^{\circ} 2.271 / 97$ :

"Art. $4^{\circ}$ É vedada a inclusão de disposições nos instrumentos contratuais que permitam:

I - indexação de preços por índices gerais, setoriais ou que reflitam a variação de custos;

Havendo regra expressa no sentido de ser vedada a repactuação de preços mediante a aplicação de índice setoriais ou gerais de preços, sem a expressa comprovação analítica da majoração dos custos contratados, deverá a Administração Pública contratante rejeitar qualquer possibilidade de repactuação de preços pela aplicação direta de índices de preços.

\section{4 - Formalizaçäo da Repactuação de Preços}

Nos termos do que determina 0 art. $65, \S 8^{\circ}$ da Lei $n^{\circ} 8.666 / 93$, a repactuação de preços pode dar-se mediante simples apostilamento nos presentes autos, desde que obedecidos os requisitos legalmente previstos para tanto.

\section{6 - A Repactuação de Preços como Meio para a Concretização do Princípio da Preservação do Equilíbrio Econômico Financeiro no Contrato Administrativo de Serviços Contínuos na Esfera Federal}

Entendendo-se a preservação da adequada relação econômica financeira do contrato administrativo como princípio setorial de Direito Administrativo, deve o mesmo, com base no valor do interesse público que o resguarda, ser considerado como vetor orientador na aplicação do direito ao caso concreto.

Significar dizer que as demais regras jurídicas, relativas à matéria, devem ser aplicadas levando-se em conta a predominância do princípio da preservação da relação econômica financeira do contrato administrativo.

Portanto, sendo a preservação da relação econômica financeira princípio de direito, havendo alteração da referida relação contratual, por qualquer motivo fático, as regras jurídicas atinentes ao caso concreto devem ser aplicadas no sentido de restabelecer, de acordo com os requisitos legalmente previstos, o ajuste às adequadas condições econômicas e financeiras originalmente pactuadas entre as partes, visando, 
precipuamente, à consecução do objeto contratual pretendido pela Administração Pública.

Ora, diante da caracterização anteriormente feita acerca da repactuação de preços, pode-se considerá-la como meio para a implementação do princípio da preservação do equilíbrio econômico financeiro nos contratos administrativos de serviços contínuos na esfera federal?

Entendemos que sim, em síntese, por três motivos. O primeiro versa sobre o fato de que a repactuação de preços, na forma como definida pela legislação vigente, considera, de forma hegemônica, a preservação da adequada relação econômica financeira entre as partes. Segundo, sendo caracterizada como negociação bilateral entre as partes, permite à Administração Pública, com pressuposto no princípio da eficiência previsto no art. 37 da Constituição da República, auferir o mesmo objeto contratual, com uma possível redução de custos para tanto, otimizando-se, portanto, a atividade administrativa. Por fim, a repactuação de preços não permite à Administração Pública, já detentora das cláusulas exorbitantes peculiares ao contrato administrativo, enriquecer-se sem justa causa, em detrimento do empobrecimento do contratado.

\section{7 - Conclusão}

A repactuação de preços - espécie de mecanismo jurídico destinado a readequar a relação econômica financeira do contrato, através da negociação bilateral que só considere as alterações de custos contratuais efetivamente demonstradas - deve ter sua aplicação pautada pela legislação que o fundamenta.

Face a isso, a Administração Pública contratante não pode conceder a repactuação de preços sem antes perquirir se os requisitos previstos no Decreto $n^{\circ} 2.271 / 97$ e na IN MARE $n^{\circ} 18 / 97$ foram devidamente cumpridos. Para tanto, deve-se verificar, nos autos de processo administrativo, o cumprimento dos seguintes requisitos para a repactuação de preços: o interregno mínimo de 01 (um) ano a contar da data da proposta ou do orçamento, a fixação do termo a quo dos efeitos da repactuação, a prévia demonstração analítica quanto à alteração dos custos contratuais, a necessidade do registro do acordo ou convenção coletiva de trabalho, a demonstração da efetiva repercussão dos fatos alegados pela contratada nos custos dos preços inicialmente pactuados, a prévia negociação bilateral entre as partes e impossibilidade de aplicação direta e imediata de índices de preços.

Cabe-nos ressaltar que a Administração Pública contratante, ao verificar os referidos requisitos, deverá considerar os princípios de direito atinentes à matéria, pois os princípios de direito, com base no hodierno posicionamento pós-positivista, detêm proeminência na aplicação do direito pátrio, devido à forte carga valorativa que os impregna.

Portanto, visando a repactuação de preços a manutenir a adequada relação econômico-financeira do contrato, sem descurar da eficiência que deve reinar na atividade administrativa, pode-se afirmar que o instituto, regulado pelo Decreto $n^{\circ}$ 2.271/97 e pela IN MARE $n^{\circ}$ 18/97, além de ser constitucional, esta em consonância 
com o principio da preservação da relação econômica financeira, sendo, inclusive, meio para sua implementação nos contratos administrativos de serviços contínuos na esfera federal.

\section{8- Referências Bibliográficas}

BARCELlOS, Ana Paula de. A Eficácia Jurídica dos Princípios Constitucionais: O Principio da Dignidade da pessoa Humana. Rio de Janeiro: Renovar, 2002.

BRASIL. Auditoria do Ministério Público da União. Pareceres. Disponível em http://www.mpu.gov.br/audin/informativos.

BRASIL. Constituição (1988). Constituição da República Federativa do Brasil. Org. Cláudio Brandão de Oliveira. Rio de Janeiro: Roma Victor, 2002.

BRASIL. Decreto $n^{\circ} 2.271$, de 7 de julho de 1997. Brasília, DF. Presidência da República, 1997.

BRASIL. Fax $n^{\circ} 739 / 2002$, de 7 de agosto de 2002. Brasília, DF. Ministério do Planejamento, Orçamento e Gestão. Secretaria de Logística e Tecnologia da Informação. Departamento de Logística e Serviços Gerais. 2002.

BRASIL. Instrução Normativa $n^{\circ} 18$, de 22 de setembro de 1997. Brasília, DF. Ministério da Administração Federal e Reforma do Estado, 1997.

BRASIL. Lei ${ }^{\circ}$ 8.666, de 21 de jutho de 1993. Brasflia, DF. D.O de 22.06.93.

BRASIL. Lei $n^{\circ}$ 10.192, de 14 de fevereiro de 2001. Brasília, DF. Senado Federal, 2001.

BRASIL. Tribunal de Contas da União. Decisão n 457/1995. Plenário. Rel. Min. Carlos Átila Alves da Silva. DOU 25.09.1995. p. 14.893 Disponível em http://www.tcu.gov.br

BRASIL. Tribunal de Contas da União. Acórdão n 55/2000. Plenário. Rel. Min. Humberto Souto. DOU 25.04.2000. Disponível em http://www.tcu.gov.br

DI PIETRO, Maria Sylvia Zanella. $5^{\mathrm{a}}$ Ed. revista e ampliada. São Paulo: Malheiros, 2001.

FILHO, José dos Santos Carvalho Filho. Manual de Direito Administrativo. Rio de Janeiro: Lumen Juris, 2000.

FILHO, Marçal Justen. Comentários à Lei de Licitações e Contratos Administrativos. 8" ed. São Paulo: Dialética, 2000.

GUSMÃO, Paulo Dourado de Gusmão. Introdução ao Estudo do Direito. Rio de Janeiro: Forense, 1988.

Informativo de Licitações e Contratos Administrativos $n^{\circ}$ 87. Maio/2001. Consulta em Destaque. São Paulo: Zênite, 2001.

Informativo de Licitações e Contratos Administrativos. $n^{\circ}$ 49. Março/1998. Comentários. São Paulo: Zênite, 1998.

Informativo de Licitações e Contratos Administrativos n 43. Setembro/1997. Perguntas e Respostas. São Paulo: Zênite, 1997.

JUNGSTEDT, Luiz Oliveira Castro. Direito Administrativo: legislação. $10^{\mathrm{a}} \mathrm{Ed}$. revista e atualizada. Rio de Janeiro: Thex Ed., 2000. 
JÚNIOR, Jessé Torres Pereira Júnior. Comentários à Lei de Licitações e Contratações da Administração Pública. $5^{a}$ ed. rev. atual. e ampl.. Rio de Janeiro: Renovar, 2002.

MAIA, Antônio Cavalcanti e Cláudio Pereira de Souza Neto. Os Princípios de Direito e as Perspectivas de Perelman, Dworkin e Alexy. In Os Princípios da Constituição de 1988. Org. Manoel Messias Peixinho e outros. Rio de Janeiro: Lumen Juris, 2001. pp. 57/99.

MEIRELLES, Hely Lopes. Direito Administrativo Brasileiro. 26a Ed. atual. São Paulo: Malheiros, 2001.

- Licitação e Contrato Administrativo. 12a Ed. São Paulo: Malheiros, 1999.

MELlo, Celso Antônio Bandeira de. Curso de Direito Administrativo. São Paulo: Malheiros, 2000.

- O Principio do enriquecimento sem Justa Causa em Direito Administrativo in Revista Diálogo Jurídico. Salvador, BA. Centro de Atualização Jurídica, v. I, $\mathrm{n}^{\circ}$ 2. Maio/2001.

MORAES, Alexandre de. Direito Constitucional. $3^{\mathbf{a}}$ Ed. São Paulo: Atlas, 1998.

— Constituição do Brasil Interpretada e Legislação Constitucional. São Paulo; Atlas, 2002.

PEIXINHO, Manoel Messias. Princípios Constitucionais da Administração Pública In os Princípios da Constituição de 1988. Org. Manoel Messias Peixinho e outros. Rio de Janeiro: Lumen Juris, 2001. p. 447/474.

PEREIRA, Jane Reis Gonçalves Pereira e outra. A Estrutura Normativa das Normas Jurídicas in In os Princípios da Constituição de 1988. Org. Manoel Messias Peixinho e outros. Rio de Janeiro: Lumen Juris, 2001. p. 03/24.

SARMENTO, Daniel. A Ponderação de Interesses na Constituição Federal. Rio de Janeiro: Lumen Juris, 2002.

TÁCITO, Caio. Temas de Direito Público; Estudos e Pareceres. $1^{\circ}$ Vol. Rio de Janeiro; Renovar, 1997.

TORRES, Ricardo Lobo. A Legitimação dos Direitos Humanos e os Principios da Ponderação e da Razoabilidade in Legitimação dos Direitos Humanos. Org. Ricardo Lobo Torres. Rio de Janeiro: Renovar, 2002. pp. 397/449. 